\title{
Milk of Polish Red and White cows as a source of nutritionally valuable fatty acids
}

\author{
Agata Adamska', Jarosława Rutkowska', Małgorzata Tabaszewska² and Małgorzata \\ Białek $^{1}$
}

'Department of Instrumental Analysis, Faculty of Human Nutrition and Consumer Sciences, Warsaw University of Life Sciences (WULS-SGGW), Warsaw, Poland, ${ }^{2}$ Faculty of Food Technology, University of Agriculture, Krakow, Poland

\begin{abstract}
Local bovine breeds are usually more resistant to diseases and better adapted to environmental and nutritional conditions than the imported ones. The aim of this study was to assess the content of individual health-related fatty acids in milk of Polish Red and White breed regarding the composition of forages. One herd of cows $(n=15)$ were fed seasonally using locally produced forages: grazed grass, containing high amounts $\left(55 \mathrm{~g} \cdot 100 \mathrm{~g} \mathrm{~g}^{-1}\right.$ fatty acid on average) of polyunsaturated fatty acid, and preserved forages, rich in saturated fatty acid (30 g.100 g ${ }^{-1}$ fatty acid on average). The content of butyric acid in milk averaged $4.21 \mathrm{~g} \cdot 100 \mathrm{~g} \mathrm{~g}^{-1}$ fatty acid regardless of season and was higher compared to that reported for other breeds. Milk from the summer season had high content (14.67 g.100 g-1 fatty acid) of total short-chain saturated fatty acid (C4:0-C12:0), that from non-pasture season (winter) had high content of odd- and branched chain fatty acids $\left(6.28 \mathrm{~g} \cdot 100 \mathrm{~g}^{-1}\right.$ fatty acid). Milk fat of studied cows had relatively lower content of nutritionally controversial myristic $\mathrm{C} 14: 0$ and palmitic $\mathrm{C} 16: 0$ acids as comparing to milk in other breeds and proved an excellent source of vaccenic acid trans-11 C18:1 and conjugated linoleic acids cis-9, trans-11 C18:2, especially during the grazing season.
\end{abstract}

Keywords: milk fat composition, effect of forages, health-related fatty acids, Polish Red-White cows

Abbreviations: CLA: conjugated linoleic acid, FA: fatty acid, FAME: fatty acid methyl esther, OBCFA: odd and branched chain fatty acids, PRW: Polish Red and White, PUFA: polyunsaturated fatty acid, SCFA: short- and medium-chain fatty acid

Archiv Tierzucht 57 (2014) 10, 1-10

Received: 2 Januar 2014

doi: $10.7482 / 0003-9438-57-010$

Accepted: 10 April 2014

Online: 23 May 2014

Corresponding author:

Jaroslawa Rutkowska, email: jaroslawa_rutkowska@sggw.pl

Department of Instrumental Analysis, Faculty of Human Nutrition and Consumer Sciences, Warsaw University of Life Sciences (WULS-SGGW), Nowoursynowska st. 159c, 02-776 Warsaw, Poland

() 2014 by the authors; licensee Leibniz Institute for Farm Animal Biology (FBN), Dummerstorf, Germany. This is an Open Access article distributed under the terms and conditions of the Creative Commons Attribution 3.0 License (http://creativecommons.org/licenses/by/3.0/). 


\section{Introduction}

Bovine milk fat is a rich source of bioactive substances offering many ingredients for the development of nutritionally valuable food products, one of the most important ones being the lipid fraction. Among all biological lipids, only few exceed bovine milk fat in the complexity of fatty acids (FAs) content and structure. Many FAs contained in bovine milk are beneficial for human health. For example, short- and medium-chain FAs (SCFA; from C4:0 to $\mathrm{C12:0)}$ have antimicrobial properties expressed by the inactivation of pathogenic strains (German \& Dillard 2006, Mills et al. 2011). Other components of milk fat of interesting biological properties are vaccenic acid trans-11 C18:1 and a large group of isomers of conjugated linoleic acid (CLA) with cis-9, trans-11 C18:2 as the dominant one and FAs having odd numbers of carbon atoms and branched chains (OBCFA) (Lock \& Bauman 2004, Mills et al. 2011).

The composition of bovine milk fat is affected by various factors (Kalač \& Samková 2010, Morales-Almaráz et al. 2010), usually divided into three subgroups: feeding, environmental and animal factors, including the breed, lactation stage and cow's individuality. The impact of the latter factor on milk composition can be determined separately or in combination with other factors (Samková et al. 2012). Various authors compare the content of various milk components from universally used cattle breed, such as Holstein-Friesian, Simmental or Jersey (Adamska \& Rutkowska 2012, Morales et al. 2000, White et al. 2001) but the reports on the quality of milk originated from indigenous breeds are scarce (Farhangfar \& Naeemipour 2007, Talpur et al. 2006, Żegarska et al. 2001, Pešek 2005). However some authors emphasised that milk from cows of local breeds included in the genetic resources conservation programme in Poland was nutritionally more valuable than from highly productive breeds and was characterised by properties favourable for processing (Litwińczuk et al. 2012).

The Polish Red and White breed (PRW) cows are bred in Poland for more than 100 years; they were brought to Poland from Westphalia, Rhineland and East Frisia. Animals of that breed have a red coat with white lower body parts and ragged patches. That breed is well adapted to harsh environmental conditions and use of pasture, is highly disease-resistant, of good health and longevity (Barłowska et al. 2009).

The milk yield of PRW cows is $4679 \mathrm{~kg}$ on average, their milk contains $4.10 \%$ of fat and $3.25 \%$ of protein, according to data for the year 2012 (PFCBDF 2013). The incidence of kappacasein B alleles is in that breed higher than in Caucasian and black-and-white HolsteinFriesian cows; milk containing that type of casein fraction is highly suitable for the cheese manufacture, cheese being of higher quality and of 5-7\% higher yield compared with other breeds (Juszczak 2001). That breed of cattle is especially popular in the southern provinces of Poland (Juszczak 2001, Sosin-Bzducha 2012) where grassland constitutes a considerable share in the structure of agricultural land.

The PRW breed is now protected by the genetic resources protection programme aimed at reconstruction of animals of an old »compact «type. In June 2006 it was decided to include the PRW breed in the breed herd book under the name of ZR, and in 2007 the programme of genetic resource conservation was introduced. According to PFCBDF (2013) data for the year 2012, the population of PRW cattle in Poland accounted for only $0.53 \%$, i.e. the PRW population counted 3446 . Upon introducing this breed (2007), there was the possibility to enter the cows with $50 \%$ participation of genes of the HF breed. Since 2013, the cows with 
$25 \%$ participation of genes of Holstein-Friesian breed might have been entered into the programme. According to the Institute of Animal Production in Balice, the number of PRW cows (ZR) participating in the programme of genetic resource conservation in 2008 and 2013 was 1715 and 2030, respectively (PFCBDF 2013). That specific conservation programme aims at decreasing the share of Holstein-Friesian genes, preserving typical traits characteristic for those old Polish cattle breeds and maintaining the within-breed genetic diversity.

The aim of the study was to assess the content of individual health-related fatty acids in bovine milk originated from the Polish Red and White breed regarding the composition of forages.

\section{Material and methods}

\section{Sampling}

A total of 32 samples of bovine milk were collected from May 2007 to April 2008 from one dairy cattle herd of PRW breed $(n=15)$ reared in the Beskidy Mountains (average altitude $725 \mathrm{~m}$ above sea level). Cows were milked twice daily by a bucket machine. The milk was pooled and stored in temperature-controlled bulk tanks at $4^{\circ} \mathrm{C}$. On average, 5 samples per season were collected except when changing the feeding regimen (spring and late autumn; 6 samples). The samples were directly transported in a cooled box to the laboratory, where fat was immediately extracted.

The nutrition of studied cows was based solely on forages planted locally; the forages in each season were sampled. During the indoor period (winter, early spring and late autumn) the nutrition of cows consisted mainly of maize silage and hay supplemented with grains (70\% triticale and $30 \%$ oat). In the grazing period (spring, summer and autumn) the cows were predominantly pasture-fed. The details of feeding are presented in Figure 1.

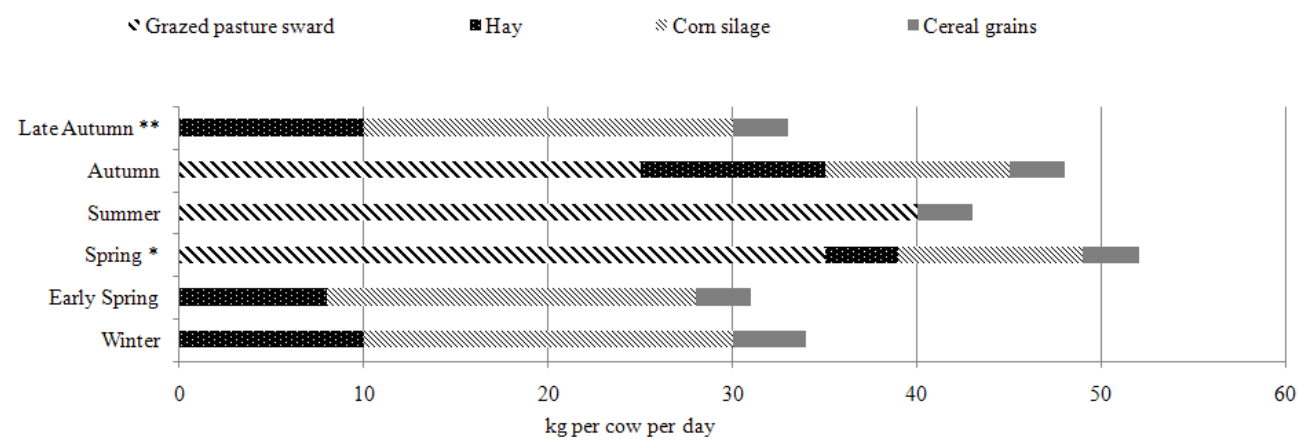

*spring: from the 20th of May, **late autumn: from the 31st of October

Figure 1

Composition of the feed ration (kg per cow per day)

Fatty acid analysis

The extraction of lipids from milk samples was carried out using the Röse-Gottlieb protocol (AOAC 2000). Fat from forage samples was extracted using the general procedure of 
Folch (Folch et al. 1957). Milk and forage FAs were converted to their methyl esters (FAME) according to AOCS Official Method Ce 2-66 and then subjected to gas chromatography using an Agilent 6890N (Agilent Tech. Inc., St. Clara, CA, USA) chromatograph equipped with flame ionisation detector, a split/splitless injector and capillary column with stationary phase of high polarity. A butter reference standard (CRM 164; Commission of the European Communities, Community Bureau of Reference, Brussels, Belgium) was used to determine the recovery rates and correction factors for individual FAs in milk samples. The term »fatty acid « or its acronym »FA« means actually the methyl ester of the respective acid (FAME), the absolute or relative contents of fatty acids are thus those of FAME throughout the text. The analytical technique was published in detail elsewhere (Rutkowska et al. 2012).

\section{Statistical analysis}

The data were subjected to one-way ANOVA and Tukey's HSD post-hoc test for uneven sample sizes to assess the between-season differences. Statistica 9 PL software (StatSoft Inc., Tulsa, OK, USA) was used, the level of $P \leq 0.05$ being considered significant.

\section{Results and discussion}

FA composition of milk is shown in Table 1. Some FAs exhibited significant $(P<0.05)$ seasonal variability. The diet of dairy cattle can affect both the content and composition of FAs. The studied cows were fed seasonally available forages produced locally (Figure 1). The forages markedly differed with respect to the content of principal groups of FAs (Figure 2). Grazed grass had considerably higher content of polyunsaturated FA (PUFA), especially in spring, compared with preserved forages (corn silage, hay), the latter containing higher levels of saturated FA than grass.

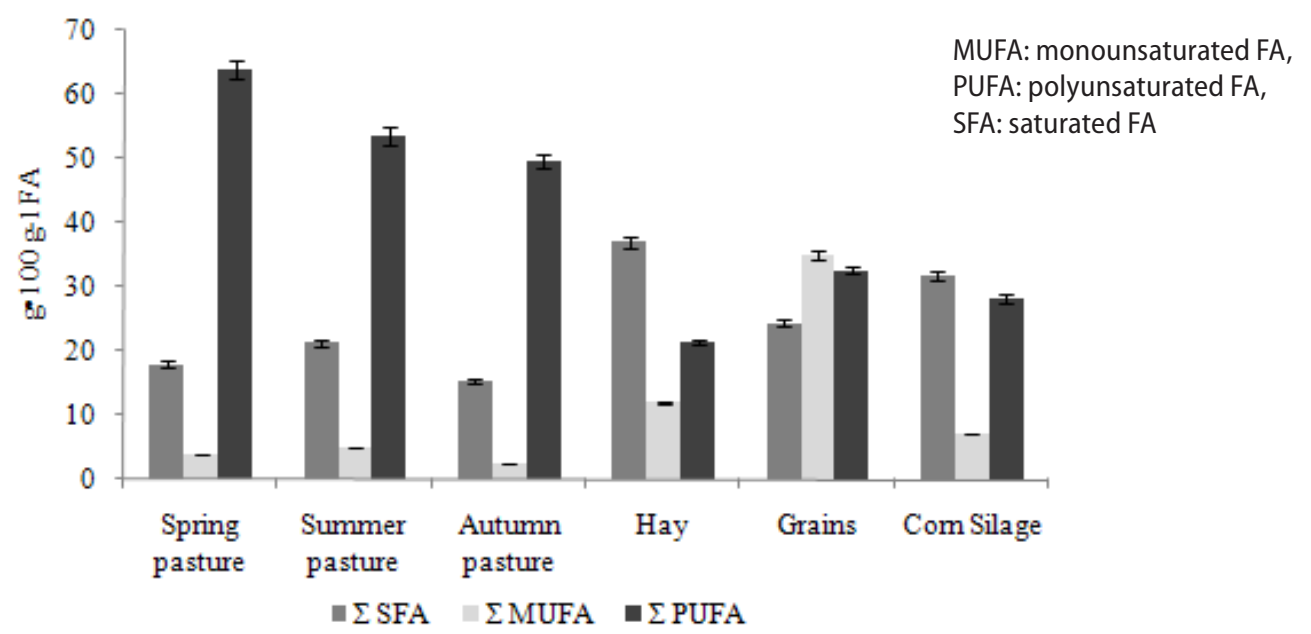

Figure 2

Fatty acid composition of forages 
Table 1

Fatty acids composition of milk fat ( $\left.\mathrm{g} \cdot 100 \mathrm{~g}^{-1} \mathrm{FA}\right)$

\begin{tabular}{|c|c|c|c|c|c|c|}
\hline Fatty acids & Winter & Early spring & Spring & Summer & Autumn & Late autumn \\
\hline C4:0 & $4.02 \pm 0.18$ & $4.18 \pm 1.73$ & $4.39 \pm 0.48$ & $4.82 \pm 0.61$ & $4.05 \pm 0.26$ & $3.79 \pm 0.57$ \\
\hline C6:0 & $2.12 \pm 0.39^{\mathrm{ab}}$ & $2.50 \pm 0.34^{\mathrm{ab}}$ & $2.28 \pm 0.28^{\mathrm{ab}}$ & $2.60 \pm 0.43^{\mathrm{a}}$ & $1.89 \pm 0.21^{b}$ & $1.61 \pm 0.24^{b}$ \\
\hline C8:0 & $1.11 \pm 0.28^{\mathrm{abc}}$ & $1.39 \pm 0.16^{\mathrm{ac}}$ & $1.28 \pm 0.11^{\mathrm{ac}}$ & $1.38 \pm 0.20^{c}$ & $0.98 \pm 0.19^{\mathrm{ab}}$ & $0.74 \pm 0.13^{b}$ \\
\hline C10:0 & $2.30 \pm 0.68^{\mathrm{ab}}$ & $2.93 \pm 0.27^{\mathrm{a}}$ & $2.80 \pm 0.17^{\mathrm{a}}$ & $2.79 \pm 0.34^{\mathrm{a}}$ & $1.06 \pm 0.52^{\mathrm{ab}}$ & $1.45 \pm 0.27^{b}$ \\
\hline C12:0 & $2.48 \pm 0.73^{\mathrm{ab}}$ & $3.19 \pm 0.31^{\mathrm{a}}$ & $3.24 \pm 0.14^{\mathrm{a}}$ & $3.09 \pm 1.75^{\mathrm{a}}$ & $2.42 \pm 0.65^{\mathrm{ab}}$ & $1.68 \pm 0.28^{b}$ \\
\hline$\Sigma$ SCFA & $12.03 \pm 2.10^{\mathrm{a}}$ & $14.19 \pm 2.80^{c}$ & $13.99 \pm 1.00^{c}$ & $14.67 \pm 1.75^{c}$ & $11.41 \pm 1.57^{a}$ & $9.26 \pm 1.42^{b}$ \\
\hline C14:0 & $9.63 \pm 2.09$ & $10.81 \pm 0.24$ & $10.83 \pm 0.45$ & $10.86 \pm 0.54$ & $9.45 \pm 1.83$ & $8.60 \pm 1.26$ \\
\hline C16:0 & $30.02 \pm 2.39$ & $28.18 \pm 2.25$ & $27.45 \pm 2.54$ & $26.91 \pm 1.25$ & $24.42 \pm 4.57$ & $27.00 \pm 4.09$ \\
\hline C18:0 & $9.68 \pm 1.60$ & $8.89 \pm 0.73$ & $8.89 \pm 0.66$ & $9.24 \pm 1.00$ & $11.45 \pm 2.46$ & $11.74 \pm 2.10$ \\
\hline C20:0 & $0.15 \pm 0.01^{\text {ac }}$ & $0.10 \pm 0.00^{\mathrm{a}}$ & $0.11 \pm 0.02^{\mathrm{a}}$ & $0.00 \pm 0.00^{\mathrm{b}}$ & $0.12 \pm 0.02^{\mathrm{a}}$ & $0.18 \pm 0.01^{c}$ \\
\hline $\mathrm{C} 22: 0$ & $0.04 \pm 0.00^{\mathrm{a}}$ & $0.04 \pm 0.00^{\mathrm{a}}$ & $0.04 \pm 0.00^{\mathrm{a}}$ & $0.05 \pm 0.01^{\mathrm{ab}}$ & $0.05 \pm 0.01^{\mathrm{ab}}$ & $0.06 \pm 0.01^{b}$ \\
\hline C24:0 & $0.06 \pm 0.03$ & $0.06 \pm 0.02$ & $0.07 \pm 0.00$ & $0.06 \pm 0.02$ & $0.06 \pm 0.01$ & $0.05 \pm 0.01$ \\
\hline$\Sigma$ LCFA & $49.58 \pm 2.97$ & $48.09 \pm 1.41$ & $47.40 \pm 2.42$ & $47.13 \pm 0.59$ & $45.55 \pm 4.24$ & $47.62 \pm 3.29$ \\
\hline C10:1 & $0.21 \pm 0.07^{\mathrm{ac}}$ & $0.29 \pm 0.11^{\mathrm{abc}}$ & $0.36 \pm 0.03^{\mathrm{ab}}$ & $0.37 \pm 0.04^{b}$ & $0.24 \pm 0.11^{\mathrm{abc}}$ & $0.15 \pm 0.04^{c}$ \\
\hline C14:1 & $0.34 \pm 0.07$ & $0.36 \pm 0.00$ & $0.46 \pm 0.06$ & $0.46 \pm 0.08$ & $0.45 \pm 0.05$ & $0.47 \pm 0.29$ \\
\hline C15:1 & $0.35 \pm 0.04^{\mathrm{a}}$ & $0.33 \pm 0.03^{\mathrm{a}}$ & $0.31 \pm 0.06^{\mathrm{a}}$ & $0.30 \pm 0.05^{\mathrm{a}}$ & $0.31 \pm 0.07^{a}$ & $0.60 \pm 0.07^{b}$ \\
\hline C16:1 n-10 & $0.50 \pm 0.09^{a}$ & $0.40 \pm 0.01^{\mathrm{a}}$ & $0.58 \pm 0.07^{\mathrm{ac}}$ & $0.49 \pm 0.08^{\mathrm{a}}$ & $0.65 \pm 0.06^{c}$ & $0.82 \pm 0.08^{b}$ \\
\hline C16:1 n-7 & $1.59 \pm 0.19$ & $1.15 \pm 0.01$ & $1.33 \pm 0.13$ & $1.37 \pm 0.17$ & $1.30 \pm 0.62$ & $1.38 \pm 0.43$ \\
\hline C17:1 & $0.56 \pm 0.09^{a}$ & $0.36 \pm 0.02^{\mathrm{bc}}$ & $0.36 \pm 0.04^{b}$ & $0.32 \pm 0.04^{b}$ & $0.32 \pm 0.07^{b}$ & $0.55 \pm 0.06^{\mathrm{ac}}$ \\
\hline Etrans isomers of C18:1 & $1.32 \pm 0.34^{\mathrm{a}}$ & $3.59 \pm 1.09^{\mathrm{ab}}$ & $4.09 \pm 0.86^{b}$ & $3.74 \pm 0.41^{\mathrm{b}}$ & $3.79 \pm 1.36^{b}$ & $1.90 \pm 0.42^{\mathrm{a}}$ \\
\hline C18:1 t-11 & $0.88 \pm 0.26^{\mathrm{a}}$ & $2.77 \pm 0.60^{\mathrm{ab}}$ & $3.47 \pm 0.94^{b}$ & $3.18 \pm 0.39^{b}$ & $3.19 \pm 1.26^{\mathrm{b}}$ & $1.39 \pm 0.42^{\mathrm{a}}$ \\
\hline C18:1 c-9 & $23.80 \pm 4.53$ & $17.88 \pm 0.81$ & $18.56 \pm 1.03$ & $19.06 \pm 0.36$ & $20.87 \pm 2.28$ & $22.85 \pm 2.38$ \\
\hline C18:1 c-11 & $0.74 \pm 0.22$ & $0.60 \pm 0.23$ & $0.43 \pm 0.05$ & $0.48 \pm 0.10$ & $0.70 \pm 0.12$ & $0.74 \pm 0.17$ \\
\hline C20:1 & $0.12 \pm 0.03^{a}$ & $0.13 \pm 0.02^{\mathrm{ab}}$ & $0.16 \pm 0.01^{\mathrm{ab}}$ & $0.14 \pm 0.04^{\text {ac }}$ & $0.18 \pm 0.02^{\mathrm{bc}}$ & $0.21 \pm 0.02^{b}$ \\
\hline ¿MUFA & $30.40 \pm 5.42$ & $27.86 \pm 2.37$ & $30.10 \pm 2.63$ & $29.90 \pm 1.01$ & $32.01 \pm 3.34$ & $31.06 \pm 2.96$ \\
\hline C18:2 n- 6 trans & $0.13 \pm 0.02^{\mathrm{a}}$ & $0.28 \pm 0.12^{\mathrm{ab}}$ & $0.31 \pm 0.01^{\mathrm{ab}}$ & $0.31 \pm 0.04^{\mathrm{ab}}$ & $0.35 \pm 0.10^{b}$ & $0.18 \pm 0.05^{\mathrm{a}}$ \\
\hline C18:2 c-9 c-12 & $1.16 \pm 0.08^{\mathrm{ac}}$ & $0.83 \pm 0.03^{\mathrm{abc}}$ & $0.80 \pm 0.06^{\mathrm{ad}}$ & $1.00 \pm 0.08^{\mathrm{acd}}$ & $0.78 \pm 0.36^{b d}$ & $1.21 \pm 0.00^{c}$ \\
\hline C18:3n-6 & $0.18 \pm 0.02^{\mathrm{ac}}$ & $0.16 \pm 0.00^{\mathrm{ac}}$ & $0.16 \pm 0.01^{\mathrm{ac}}$ & $0.16 \pm 0.03^{c}$ & $0.22 \pm 0.04^{\mathrm{a}}$ & $0.31 \pm 0.02^{\mathrm{b}}$ \\
\hline C18:3 c-9 c-12 c-15 & $0.49 \pm 0.06^{\mathrm{a}}$ & $0.63 \pm 0.06^{\mathrm{ab}}$ & $0.64 \pm 0.10^{\mathrm{ac}}$ & $0.91 \pm 0.10^{b}$ & $0.87 \pm 0.15^{\text {bc }}$ & $0.92 \pm 0.12^{\mathrm{b}}$ \\
\hline C18:2 c-9 t-11 & $0.39 \pm 0.06^{\mathrm{a}}$ & $1.16 \pm 0.44^{\mathrm{ab}}$ & $1.71 \pm 0.44^{\mathrm{b}}$ & $1.53 \pm 0.22^{b}$ & $1.32 \pm 0.38^{b}$ & $0.59 \pm 0.12^{\mathrm{a}}$ \\
\hline$C 20: 3 n-6$ & $0.08 \pm 0.01^{\mathrm{a}}$ & $0.08 \pm 0.00^{\mathrm{a}}$ & $0.10 \pm 0.01^{\text {ac }}$ & $0.11 \pm 0.03^{\mathrm{ac}}$ & $0.13 \pm 0.02^{\mathrm{bc}}$ & $0.16 \pm 0.00^{b}$ \\
\hline$C 20: 3 n-3$ & $0.09 \pm 0.01$ & $0.08 \pm 0.01$ & $0.07 \pm 0.00$ & $0.08 \pm 0.02$ & $0.09 \pm 0.02$ & $0.10 \pm 0.05$ \\
\hline$C 20: 5 n-3$ & $0.05 \pm 0.01^{\mathrm{a}}$ & $0.07 \pm 0.01^{\mathrm{a}}$ & $0.08 \pm 0.01^{\mathrm{a}}$ & $0.07 \pm 0.00^{\mathrm{a}}$ & $0.08 \pm 0.01^{\mathrm{a}}$ & $0.10 \pm 0.01^{b}$ \\
\hline$\Sigma$ PUFA & $2.57 \pm 0.23^{\mathrm{a}}$ & $3.28 \pm 0.65^{b}$ & $3.88 \pm 0.43^{b}$ & $4.18 \pm 0.45^{b}$ & $3.83 \pm 0.44^{b}$ & $3.56 \pm 0.42^{\mathrm{b}}$ \\
\hline iso $\mathrm{C} 10: 0$ & $0.02 \pm 0.00$ & $0.02 \pm 0.01$ & $0.03 \pm 0.00$ & $0.00 \pm 0.00$ & $0.10 \pm 0.00$ & $0.00 \pm 0.00$ \\
\hline C11:0 & $0.03 \pm 0.01$ & $0.04 \pm 0.02$ & $0.04 \pm 0.01$ & $0.03 \pm 0.00$ & $0.02 \pm 0.01$ & $0.06 \pm 0.07$ \\
\hline anteiso $\mathrm{C} 12: 0$ & $0.03 \pm 0.01^{\mathrm{a}}$ & $0.04 \pm 0.00^{\mathrm{ab}}$ & $0.05 \pm 0.01^{b}$ & $0.06 \pm 0.01^{b}$ & $0.05 \pm 0.01^{\mathrm{b}}$ & $0.06 \pm 0.00^{b}$ \\
\hline iso $\mathrm{C} 12: 0$ & $0.05 \pm 0.02^{\mathrm{ac}}$ & $0.07 \pm 0.03^{\mathrm{ab}}$ & $0.10 \pm 0.01^{b}$ & $0.09 \pm 0.01^{\mathrm{bc}}$ & $0.07 \pm 0.01^{\mathrm{ab}}$ & $0.04 \pm 0.01^{\mathrm{a}}$ \\
\hline iso $\mathrm{C} 13: 0$ & $0.05 \pm 0.02^{\mathrm{ac}}$ & $0.05 \pm 0.02^{\mathrm{ab}}$ & $0.11 \pm 0.02^{b}$ & $0.10 \pm 0.01^{\mathrm{bc}}$ & $0.07 \pm 0.04^{\mathrm{ab}}$ & $0.04 \pm 0.01^{\mathrm{a}}$ \\
\hline C13:0 & $0.08 \pm 0.01^{\mathrm{a}}$ & $0.09 \pm 0.01^{\mathrm{ab}}$ & $0.09 \pm 0.01^{\mathrm{ab}}$ & $0.08 \pm 0.01^{\mathrm{ab}}$ & $0.07 \pm 0.04^{\mathrm{a}}$ & $0.11 \pm 0.02^{b}$ \\
\hline iso $\mathrm{C} 14: 0$ & $0.18 \pm 0.03^{\mathrm{a}}$ & $0.17 \pm 0.01^{\mathrm{a}}$ & $0.17 \pm 0.04^{\mathrm{a}}$ & $0.18 \pm 0.03^{\mathrm{a}}$ & $0.07 \pm 0.01^{\mathrm{a}}$ & $0.31 \pm 0.06^{b}$ \\
\hline anteiso $\mathrm{C} 15: 0$ & $0.56 \pm 0.13$ & $0.72 \pm 0.05$ & $0.78 \pm 0.11$ & $0.69 \pm 0.13$ & $0.62 \pm 0.06$ & $0.80 \pm 0.20$ \\
\hline iso $\mathrm{C} 15: 0$ & $0.74 \pm 0.14$ & $0.83 \pm 0.29$ & $1.22 \pm 0.12$ & $1.19 \pm 0.20$ & $0.95 \pm 0.58$ & $0.68 \pm 0.26$ \\
\hline C15:0 & $1.08 \pm 0.20^{\mathrm{a}}$ & $1.32 \pm 0.16^{\mathrm{a}}$ & $1.43 \pm 0.14^{\mathrm{a}}$ & $1.32 \pm 0.13^{\mathrm{a}}$ & $1.27 \pm 0.18^{\mathrm{a}}$ & $1.91 \pm 0.28^{b}$ \\
\hline iso $\mathrm{C} 16: 0$ & $0.06 \pm 0.01^{\mathrm{a}}$ & $0.09 \pm 0.00^{\mathrm{ab}}$ & $0.15 \pm 0.08^{\mathrm{ab}}$ & $0.20 \pm 0.04^{b}$ & $0.18 \pm 0.04^{b}$ & $0.13 \pm 0.04^{\mathrm{ab}}$ \\
\hline anteiso $\mathrm{C} 17: 0$ & $0.60 \pm 0.05$ & $0.57 \pm 0.06$ & $0.53 \pm 0.09$ & $0.53 \pm 0.22$ & $0.46 \pm 0.05$ & $0.69 \pm 0.09$ \\
\hline iso $\mathrm{C} 17: 0$ & $0.06 \pm 0.02$ & $0.08 \pm 0.00$ & $0.15 \pm 0.04$ & $0.13 \pm 0.02$ & $0.10 \pm 0.08$ & $0.07 \pm 0.02$ \\
\hline C17:0 & $0.86 \pm 0.06^{\mathrm{a}}$ & $0.76 \pm 0.02^{\mathrm{a}}$ & $0.77 \pm 0.15^{\mathrm{a}}$ & $0.72 \pm 0.09^{\mathrm{a}}$ & $0.73 \pm 0.15^{\mathrm{a}}$ & $1.13 \pm 0.04^{b}$ \\
\hline C21:0 & $0.07 \pm 0.03^{\mathrm{a}}$ & $0.07 \pm 0.01^{\mathrm{a}}$ & $0.11 \pm 0.03^{\mathrm{a}}$ & $0.10 \pm 0.04^{\mathrm{a}}$ & $0.19 \pm 0.08^{b}$ & $0.19 \pm 0.00^{b}$ \\
\hline C23:0 & $0.02 \pm 0.00^{\mathrm{a}}$ & $0.02 \pm 0.00^{\text {ac }}$ & $0.04 \pm 0.01^{b c}$ & $0.04 \pm 0.01^{\mathrm{abc}}$ & $0.05 \pm 0.01^{\mathrm{bd}}$ & $0.06 \pm 0.00^{d}$ \\
\hline$\Sigma O B C F A$ & $4.48 \pm 0.32^{\mathrm{a}}$ & $4.96 \pm 0.34^{b}$ & $5.78 \pm 0.49^{b c}$ & $5.48 \pm 0.43^{b}$ & $5.11 \pm 0.68^{b}$ & $6.28 \pm 0.82^{c}$ \\
\hline
\end{tabular}

LCFA: long chain FA, MUFA: monounsaturated FA, OBCFA: odd and branched chain FA, PUFA: polyunsaturated FA, SCFA: short- and medium-chain FAValues for given fatty acids, bearing different superscripts, significantly differ from each other $(P \leq 0.05)$. 
Most of the SCFA (C4:0 to C14:0) in milk are produced by de novo synthesis. Acetate and butyric acid are generated in the rumen by fermentation of feed components, butyric acid being converted to $\beta$-hydroxybutyrate during absorption by rumen epithelium (Mills et al. 2011). The SCFA content in milk fat raises increased concern as those acids do not contribute to adiposity thus being considered to have a beneficial impact on human health (Barłowska et al. 2006). The content of butyric acid C4:0 in milk is relatively little affected by the type of feeding regimen and season (Staerfl et al. 2013). That report confirmed our results that the content of butyric was not season-dependent. Similar observation was reported for mountainous farms in the Czech Republic (Frelich et al. 2009) but a reverse trend was observed when milk from the Black-White breed of cattle was analysed (Rutkowska et al. 2012). Regardless of season, the content of butyric acid in this study was higher compared with African breeds studied by Myburgh et al. (2012). The average content of anticancerogenic C4:0 in our study $\left(4.20 \mathrm{~g} \cdot 100 \mathrm{~g}^{-1} \mathrm{FA}\right)$ was also by about $25 \%$ higher than in milk from the mountainous region in Switzerland ( $3.38 \mathrm{~g} \cdot 100 \mathrm{~g}^{-1} \mathrm{FA}$ ) (Collomb et al. 2008).

Among other FAs belonging to this group (C6:0-C12:0), seasonal variations were noted. Total content of SCFA in milk was lowest in autumn (10.33 g.100 $\mathrm{g}^{-1} \mathrm{FA}$ on average), and highest in summer (14.67 g.100 g $\mathrm{g}^{-1} \mathrm{FA}$ ) and early spring. Barłowska et al. (2009) found higher total SCFA in milk of Red-White variety of Holstein-Friesian in winter, when cows were fed hay and corn silages containing high amounts of saturated FA, than in summer, when large amounts of PUFA derived from pasture were consumed. A remarkable advantage of PRW milk fat is also a relatively lower level of myristic C14:0 and palmitic C16:0 acids even in winter season, as compared with the data of Samková et al. (2012) and of Brzóska (2006) and Pešek et al. (2005). It is to be noted that those acids are controversial from the human nutrition point of view.

The unique feature of ruminants is that their fat contains FAs having odd numbers of carbon atoms and branched chains - OBCFA. Those acids are capable of inhibiting cancer cell proliferation and differentiation as well as of inducing apoptosis in a number of cancer cell lines. OBCFA can also be used as an indicator of dairy product intake by human beings. The source of OBCFAs in milk fat is mainly ruminal synthesis but they may be also formed in the mammary gland (Vlaeminck et al. 2006). Milk fat of PRW cows contained high levels of OBCFA ranging from 4.48 to $6.28 \mathrm{~g} \cdot 100 \mathrm{~g}^{-1} \mathrm{FA}$ in winter and late autumn, respectively (Table 1). Similarly high OBCFA content was found by us in milk of Black-White cows also bred in a mountainous region and fed like the discussed PRW cows (Rutkowska et al. 2012).

The microbial synthesis of branched-chain FA seems to be enhanced by fibre-rich diets (Staerfl et al. 2013). This was confirmed by our results, as highest content of branched-chain FA was observed in late autumn $\left(2.85 \mathrm{~g} \cdot 100 \mathrm{~g}^{-1} \mathrm{FA}\right)$ probably because of intake of fibre-rich hay, and in summer $\left(3.10 \mathrm{~g} \cdot 100 \mathrm{~g}^{-1} \mathrm{FA}\right)$ when cows consumed matured grass also rich in fibre, the amounts of branched-chain FA being higher than those reported by Collomb et al. (2008) in milk samples derived from mountainous farms in Switzerland. It is worth noting that the presence of OBCFA in milk of PRW cows is unique among indigenous breeds of cattle studied in Africa (Myburgh et al. 2012), Iran (Bassiri et al. 2012), Malaysia (Yassir et al. 2010) and Czech Republic (Pešek et al. 2005).

Fatty acids arise in bovine milk fat from two sources: de novo synthesis in the mammary gland and plasma lipids originating from feedstuffs. Dietary lipids consist largely of glycolipids, phospholipids and triacylglycerols, and the major FAs are linoleic acid (cis-9 cis-12 C18:2) and 
linolenic acid (cis-9 cis-12 cis-15 C18:3). In the rumen, these lipids are hydrolysed initially to produce non-esterified FAs, which are then subjected to extensive biohydrogenation by microorganisms (mainly Butyrivibrio fibrisolvens). Ruminal biohydrogenation of dietary PUFAs generates a wide array of isomeric unsaturated FAs that are absorbed and may be transferred into milk. The first intermediate formed in this step is cis-9 trans-11 C18:2 - a major isomer of conjugated linoleic acid (CLA; Song \& Kennelly 2003) which can be converted via reduction into trans-11 C18:1 and stearic (C18:0) acids. Because of that, the supply of linoleic acid and linolenic acid in feed is of great importance. We observed a steadily increasing intake of these FAs beginning at the access of cows to pasture (Figure 3 ) attaining maximum in summer, when the cows consumed $40 \mathrm{~kg}$ of sward per day (Figure 1). This resulted in markedly higher content of PUFAs in milk fat from the grazing period, especially in summer $\left(4.18 \mathrm{~g} \cdot 100 \mathrm{~g}^{-1} \mathrm{FA}\right)$. That level was nearly twice higher compared with the data of Grega et al. (2005) reported for the Red-White breed of cows fed similarly as ours experimental PRW herd. Also, fat from milk of indigenous breeds of African and Malaysian dairy cattle contained lower levels of PUFAs $-2.61 \mathrm{~g} \cdot 100 \mathrm{~g} \mathrm{~g}^{-1}$ and $2.12 \mathrm{~g} \cdot 100 \mathrm{~g}^{-1}$, respectively (Myburgh et al. 2012, Yassir et al. 2010). Higher content of that FA group in milk from Czech Pied breed $\left(6.67 \mathrm{~g} \cdot 100 \mathrm{~g}^{-1}\right)$ was probably due to feeding cows maize and alfalfa silages with addition of barley, wheat and soy (Pešek et al. 2005).

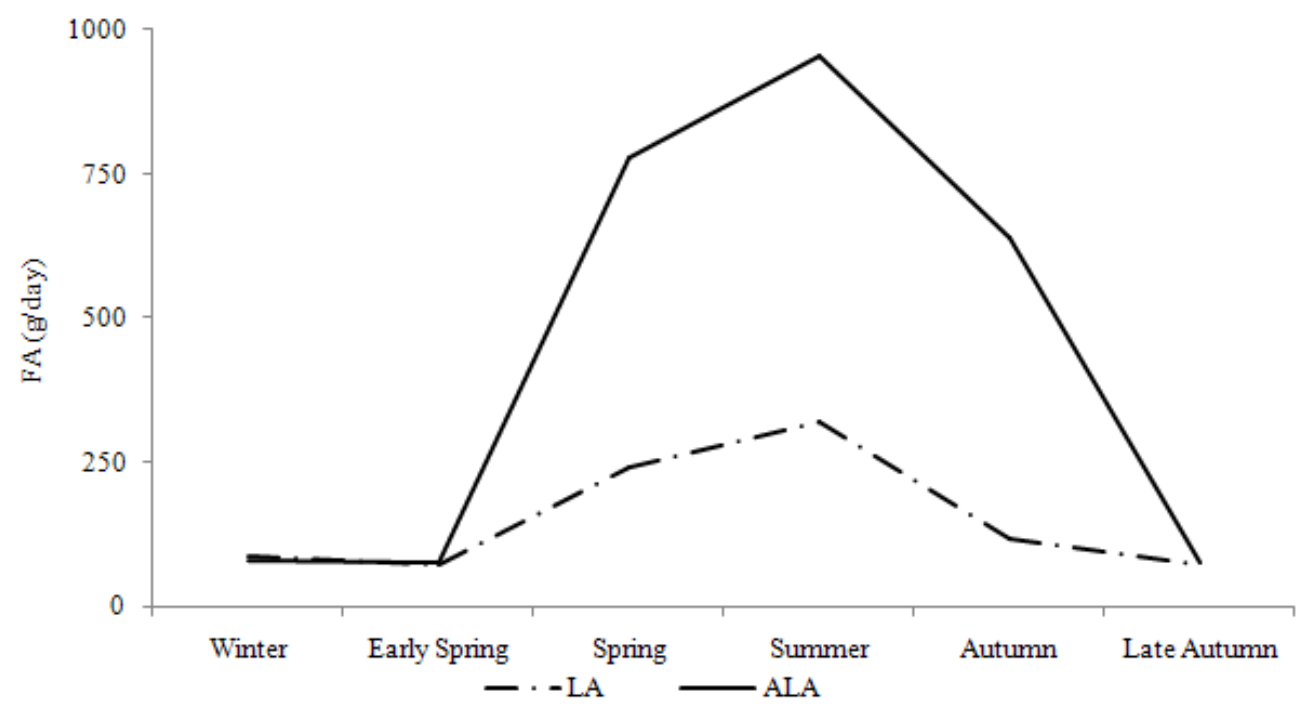

ALA: linolenic acid, LA: linoleic acid

Figure 3

Daily intake (g/day) of cis-9 cis-12 C18:2 (linoleic) and cis-9 cis-12 cis-15 C18:3 (linolenic) acids from forage

Fatty acids resulting from biohydrogenation are esterified to triacylglycerols and enter the bloodstream in chylomicrons. Those triacylglycerols are taken up by the mammary gland and cleaved to produce non-esterified FAs. The mammary gland contains the stearoyl-CoA 
desaturase ( $\Delta$ 9-desaturase), an enzyme capable to convert vaccenic acid into $C L A$. The content of trans-11 C18:1 proved to be significantly $(P<0.05)$ season-dependent and ranged from 0.88 to $3.47 \mathrm{~g} \cdot 100 \mathrm{~g}^{-1} \mathrm{FA}$ in winter and spring, respectively. The highest CLA cis-9 trans-11 C18:2 content in milk was found in the summer pasture grazing period $\left(1.71 \mathrm{~g} \cdot 100 \mathrm{~g}^{-1} \mathrm{FA}\right)$, the lowest one in the indoor feeding period $\left(0.39 \mathrm{~g} \cdot 100 \mathrm{~g}^{-1} \mathrm{FA}\right)$ in winter. Similar trend was observed by us for trans-11 C18:1 - a threefold increase following the introduction of grazing and a dramatic decline after its termination. These results are consistent with the reports of other authors who studied fatty acid composition of milk fat from cows bred in a mountainous region (Collomb et al. 2008, Frelich et al. 2009) and who reported a high content of both vaccenic acid and CLA to be associated with grazing, and the same was also confirmed for BlackWhite breed (Rutkowska et al. 2012). In this study, the content of CLA in the grazing season proved threefold higher than that reported by Barłowska et al. (2006) for Holstein-Friesian Red-White cows. Animals of that breed supplemented with different levels of calcium salts of FA produced milk with CLA levels comparable with those in the pasture period in our study (Brzóska 2006). The content of CLA noted in our study was higher than in milk from Whitebacked and Polish Black-and-White cows, but lower than in the Polish Red ones, all of them included in the genetic resources conservation programme (Litwińczuk et al. 2012).

In conclusion, milk yielded by PRW cows reared in a mountainous regions is one of the best sources of PUFA, including vaccenic acid (trans-11 C18:1) and CLA (cis-9 trans-11 C18:2), odd- and branched-chain fatty acids and butyric acid, especially during the grazing season. The observed fatty acid composition of PRW milk fat is consistent with literature data that milk fats of indigenous breeds have a more desirable profile than highly productive breeds, such as Holstein-Friesian. Thus, initiatives including promotion of native dairy cattle breeds as a source of valuable and functional ingredients should be supported. The importance of country-specific composition values of bovine milk becomes apparent and should be used as accurate reference data for both dietary advice and industry purposes. Thus, producing and promoting milk with the greatest proportion of desirable components ought to be supported.

\section{References}

Adamska A, Rutkowska J (2012) [Seasonal changes in triacylglycerols composition in milk fat from Simmental cows in Mazovia region]. Zywn-Nauk Technol Ja 5, 145-154 [in Polish]

AOAC (2000) Official Methods of Analysis of the AOAC, No. 905.02. Gravimetric method. 17th ed., Arlington, VA, USA

AOCS (2000) Official Method Ce 2-66. Preparation of methyl esters of fatty acids. American Oil Chemists' Society, Urbana, IL, USA

Barłowska J, Grodzicki T, Topyła B, Litwińczuk Z (2009) Physicochemical properties of milk fat from three breeds of cows during summer and winter feeding. Arch Tierz 52, 356-363

Barłowska J, Litwińczuk Z, Król J, Kędzierska-Matysek M (2006) Fatty acid profile and minerals content in milk from cows of various breeds over spring-summer feeding period. Pol J Food Nutr Sci 15/56 (Special Issue), 13-16

Bassiri S, Taghizadeh A, Angadji L, Fard MD, Tofigi AA (2012) The comparison of lactation performance and milk fatty acid composition of Sarabi indigenous and Holstein cows. J Cell Anim Biol 6, 182-187

Brzóska F (2006) Effect of fatty acid calcium salts from linseed oil on the yield and n-3 fatty acid content of milk and on blood plasma parameters of cows. J Anim Feed Sci 15, 347-360 
Collomb M, Bisig W, Bütikofer U, Sieber R, Bregy M, Etter L (2008) Fatty acid composition of mountain milk from Switzerland: Comparison of organic and integrated farming systems. Int Dairy J 18, 976-982

Farhangfar H, Naeemipour H (2007) Phenotypic Study of Lactation Curve in Iranian Holsteins. J Agric Sci Technol 9, 279-286

Folch J, Lees M, Sloane Stanley GH (1957) A simple method for the isolation and purification of total lipides from animal tissues. J Biol Chem 226, 497-509

Frelich J, Šlachta M, Hanuš O, Špička J, Samková E (2009) Fatty acid composition of cow milk fat produced on low-input mountain farms. Czech J Anim Sci 12, 532-539

German JB, Dillard CJ (2006) Composition, Structure and Absorption of Milk Lipids: A Source of Energy, FatSoluble Nutrients and Bioactive Molecules. Crit Rev Food Sci Nutr 46, 57-92

Grega T, Sady M, Najgebauer D, Domagała J, Faber B (2005) Bioactive components of milk from different cow breeds. Biotech Anim Husbandry 21, 35-38

Juszczak J (2001) [Polish Red-White cattle: threats and prospects of development of breed]. Przegląd Hodowlany 6, 16-17 [in Polish]

Kalač P, Samková E (2010) The effects of feeding various forages on fatty acid composition of bovine milk fat: A review. Czech J Anim Sci 55, 521-537

Litwińczuk Z, Barłowska J, Chabuz W, Brodziak A (2012) Nutritional Value and Technological Suitability of Milk from Cows of Three Polish Breeds Included in the Genetic Resources Conservation Programme. Ann Anim Sci 12, 423-432

Lock AL, Bauman DE (2004) Modifying milk fat composition of dairy cows to enhance fatty acids beneficial to human health. Lipids 39, 1197-1206

Mills S, Ross RP, Hill C, Fitzgerald GF, Stanton C (2011) Milk intelligence: Mining milk for bioactive substances associated with human health. Int Dairy J 21, 377-401

Morales MS, Palmquist DL, Weiss WP (2000) Milk Fat Composition of Holstein and Jersey Cows with Control of Depleted Copper Status and Fed Whole Soyabeans or Tallow. J Dairy Sci 83, 2112-2119

Morales-Almaráz E, Soldado A, González A, Martínez-Fernández A, Domínguez-Vara I, de La Roza-Degaldo B, Vicente $F(2010)$ Improving the fatty acid profile of dairy cow milk by combining grazing with feeding of total mixed ration. J Dairy Res 77, 225-230

Myburgh J, Osthoff G, Hugo A, de Wit M, Nel K, Fourie D (2012) Comparison of the milk composition of freeranging indigenous African cattle breeds. S Afr J Anim Sci 42, 1-14

Pešek M, Špička J, Samková E (2005) Comparison of fatty acid composition in milk fat of Czech Pied cattle and Holstein cattle. Czech J Anim Sci 50, 122-128

PFCBDF (2013) Polish Federation of Cattle Breeders and Dairy Farmers Report, http://www.pfhb.pl/ english/?strona=milk_rec.htm [last accessed 03.05.2014]

Rutkowska J, Adamska A, Bialek M (2012) Fatty acid profile of the milk of cows reared in the mountain region of Poland. J Dairy Res 79, 469-476

Samková E, Špička J, Pešek M, Pelikánová T, Hanuš O (2012) Animal factors affecting fatty acid composition of cow milk fat: a review. S Afr J Anim Sci 42, 83-100

Song MK, Kennelly JJ (2003) Biosynthesis of Conjugated Linoleic Acid and Its Incorporation into Ruminant's Products. Asian-Aust J Anim Sci 16, 306-314

Sosin-Bzducha E (2012) [Characteristics of the Polish Red-and-White cattle population included in the genetic resources conservation programme in 2008-2011]. Rocz Nauk Zoot 39, 3-16 [in Polish]

Staerfl SM, Zeitz JO, Amelchanka SL, Kälber T, Kreuzer M, Leiber F (2013) Comparison of the milk fatty acid composition from dairy cows fed high-sugar ryegrass, low-sugar ryegrass, or maize. Dairy Sci Technol 93, 201-210

Talpur FN, Bhanger MI, Khuhawar MY (2006) Comparison of fatty acids and cholesterol content in the milk of Pakistani cow breeds. J Food Compos Anal 19, 689-703 
Vlaeminck B, Fievez V, Cabrita ARJ, Fonesca AJM, Dewhurst RJ (2006) Factors affecting odd- and branchedchain fatty acids in milk: A review. Anim Feed Sci Technol 131, 389-417

White SL, Bertrand JA, Wade MR, Washburn SP, Green JT Jr, Jenkins TC (2001) Comparison of Fatty Acid Content of Milk from Jersey and Holstein Cows Consuming Pasture or Total Mixed Ration. J Dairy Sci 84, 2295-2301

Yassir MA, Arifah AK, Yaakub H, Zuiraini A, Zakaria ZA (2010) Comparison of Conjugated Linoleic Acid and Other Fatty Acid Content of Milk Fat of Mafriwal and Jersey Cows. J Anim Vet Adv 9, 1318-1323

Żegarska Z, Jaworski J, Paszczyk B, Charkiewicz J, Borejszo Z (2001) Fatty acids composition with emphasis on trans C18:1 isomers of milk fat from Lowland and Black-and-White and Polish Red cows. Pol J Food Nutr Sci 10, 41-44 